\title{
Size at Sexual Maturity of Female Northern Shrimp (Pandalus borealis Krøyer) in the Denmark Strait 1985-93 and a Comparison with the nearest Icelandic Shrimp Populations
}

\author{
U. Skúladóttir \\ Marine Research Institute, Skúlagata 4, \\ P. O. Box 1390, 121 Reykjavík, Iceland
}

\begin{abstract}
Sexual maturity of female northern shrimp Pandalus borealis in the Denmark Strait was calculated from logistic curves for the years 1985-93 and compared to similar data from nearby offshore and inshore shrimp grounds in Icelandic waters. The median maturity lengths of females in the Denmark Strait were by far the largest through all the years, at $27.9 \mathrm{~mm}$ on average compared to $23.8-24.3 \mathrm{~mm}$ for the nearest offshore Icelandic waters and 18.9-20.8 $\mathrm{mm}$ for four inshore areas. The differences in mean median maturity lengths of females could be related to differences in near-bottom water temperature.
\end{abstract}

Key words: female maturity length, Icelandic waters, Pandalus borealis

\section{Introduction}

The Pandalid shrimp are generally protandric hermaphrodites, which reproduce first as males and subsequently change into females and spawn as such for the rest of their lives. In Icelandic waters all individuals of northern shrimp Pandalus borealis start as males, and primary females, i.e. individuals which are female all their life, have never been found.

Maturity ogives which are commonly used for studies of various species was found to be a useful tool in this study. Usually the ogive is calculated for each sex (male and female) and the curve chosen is sigmoid or s-shaped. Often probit analysis is used to fit this type of curve (Bliss, 1934). Also the method of Ashton (1972) has been popular, turning the proportions of mature females or males into socalled logits, and fitting a straight line to those. For $P$. borealis Skúladóttir and Jónsson (1980) found it suitable to use the proportion of mature females (egg bearing) against all shrimp per length-class, as a basis for an s-shaped maturity ogive, drawn by hand. The median maturity length $\left(\mathrm{L}_{50}\right)$ is then read off where $50 \%$ of the specimens in a length-class are mature females. They reported on $\mathrm{L}_{50}$ of P. borealis in various inshore and a few offshore areas in Icelandic waters for the years 1977-79, as well as on the variation within one fjord for the years 1961-80. Charnov and Anderson (1989) studied the size at sex change of northern shrimp in Pavlof Bay using the same criterion of proportion of females by length-classes, and maintained that there was a great interannual variation in both size and age at sex change.

Rasmussen (1953) indicated that sex change is related to size of individuals rather than age, and he considered that age at sex change shows considerable geographic variation. Appolonio et al. (1986) maintained that temperature plays a significant role in determining the time (age) of sex change. The findings of Skúladóttir et al. (MS 1991), studying the variation of female maturity in four areas within Icelandic waters, did support the last mentioned theory, but not the theory of Rasmussen (1953) that size at sex change is almost the same in different areas. Skúladóttir et al. (MS 1991) also studied the variation in size at sex change more accurately for all shrimp grounds in Icelandic waters in the years 1988 and 1989 using the sternal spines criterion, i.e. the absence of sternal spines to identify female shrimp that have spawned at least once (McCrary, 1971). They also used a straight line (Skúladóttir, MS 1990) instead of the logistic curve to determine the $\mathrm{L}_{50}$. 
In this study the $\mathrm{L}_{50}$ for female maturity of northern shrimp in Denmark Strait are given for the years 1985-1993, based on the sternal spine criterion but fitting the logistic maturity curve directly to all samples by month and area. For comparison similar data from approximately the same months and years are given for the nearest Icelandic shrimp populations, and differences between areas in mean $\mathrm{L}_{50}$ are put in relation to available data on nearbottom temperatures.

\section{Materials and Methods}

\section{Biological samples}

Shrimp samples were obtained both from commercial Icelandic vessels and from research surveys. About half of the Denmark Strait samples from September 1987 came from a Norwegian survey. The number of shrimp measured per month are presented in Table 1. In all cases a mesh size of 35-36 mm was used in the codend. Oblique carapace length (Rasmussen, 1953) of shrimp was measured to the nearest $0.5 \mathrm{~mm}$ using sliding calipers. The samples were either measured fresh or after thawing frozen samples.

The main strata numbers of the areas investigated in the Denmark Strait (Strata Numbers 626628 and 676-678) and in Icelandic waters are shown in Figure 1, in addition to the location of the temperature station L9.

\section{Determination of the median maturity length $\left(\mathbf{L}_{50}\right)$}

For each sample the proportion between the number of females without sternal spines and all specimens was calculated for every length-class. However, for the months September through December identification of mature female shrimp from the inshore strata 573 and 622 (Fig. 1) was based on the presence of egg bearing (or in September, alternatively the presence of green roe under the carapace), as all females in inshore areas spawn annually.

The method used to estimate the maturity ogive of mature females was based on fitting of the sigmoid, logistic curve first described by Pearl and Reed (1920). The equation used is:

$$
y=1 /\left(1+e^{-(a+b x)}\right)
$$

where $y$ is the estimated proportion of mature female shrimp, $x$ is the carapace length, $a$ is the coefficient, and $b$ is the coefficient for the steepness of the logistic curve

The logistic curve was fitted by least squares to the afore-mentioned proportions per length-class of all the samples individually for each month in every area, using maximum likelihood iterations. From this the inflection point at $\mathrm{L}_{50}$ of the logistic curve, i.e. the length where $50 \%$ of the specimens are mature females, was calculated. This carapace length is also called median length $\left(\mathrm{L}_{50}\right)$. The overall mean $\mathrm{L}_{50}$ over all years was then calculated for every area using the $\mathrm{L}_{50}$ of a month as one sample.

The $\mathrm{L}_{50}$ values for female sexual maturity were compared between each pair of areas using first a variance test (Bailey, 1959). If the two variances were assessed to be equal, the difference between the means was calculated in the traditional manner obtaining the value of $t$ for the difference between the two means and comparing it to the appropriate $t$-value in the $t$-table. If however the variances were unequal, an approximation was used when calculating the $t$-value for the difference as described by Bailey (1959).

\section{Temperature and currents}

Information on temperature was extracted from the standard hydrographic Látrabjarg section sampled by the Marine Research Institute (MRI) Reykjavik usually four times a year. The westernmost station, Number 9 (L9, Fig. 1), was considered the best available representative for the Denmark Strait area. The temperature was measured at different depth intervals through the years (every 40,50 or some years at every $100 \mathrm{~m}$ depth). The average temperatures for the depth ranges 300$410 \mathrm{~m}$ and $420-540 \mathrm{~m}$ were calculated. For each depth range, the mean temperature was then calculated by quarter over the years 1981-92 before calculating an overall mean for the whole period.

Figure 2 shows the system of ocean currents around Iceland. The warm Irminger current from the south meets the cold East Greenland current in Denmark Strait. The coastal current is warmest along the south coast of Iceland but gets gradually colder when proceeding clockwise around the country. A detailed description of the different water masses is given by Malmberg and Kristmannsson (1992). 
TABLE 1. The number of shrimp measured and used for the calculation of $\mathrm{L}_{50}$.

\begin{tabular}{|c|c|c|c|c|c|c|c|}
\hline \multirow[b]{2}{*}{$\begin{array}{l}\text { Year } \\
\text { Month }\end{array}$} & \multirow[b]{2}{*}{$\begin{array}{c}\text { Denmark Strait } \\
627-629 \\
676-679\end{array}$} & \multicolumn{6}{|c|}{ Areas and Strata Numbers } \\
\hline & & $\begin{array}{l}\text { Hali } \\
674-675\end{array}$ & $\begin{array}{c}\text { Nordurkantur } \\
720-724\end{array}$ & $\begin{array}{c}\text { Ísafjardardjup } \\
622\end{array}$ & $\begin{array}{c}\text { Arnarfjordur } \\
573\end{array}$ & $\begin{array}{c}\text { Snaefellsnes } \\
474 \\
523-524\end{array}$ & $\begin{array}{c}\text { Eldey } \\
373\end{array}$ \\
\hline \multicolumn{8}{|c|}{1985} \\
\hline $\begin{array}{l}\text { July } \\
\text { August } \\
\text { Sept/Oct } \\
\text { November } \\
\text { December }\end{array}$ & $\begin{array}{l}402 \\
395 \\
\\
941 \\
138\end{array}$ & & 407 & $\begin{array}{l}4679 \\
3024\end{array}$ & $\begin{array}{r}608 \\
2306\end{array}$ & $\begin{array}{l}1621 \\
1913\end{array}$ & $\begin{array}{ll}1 & 454 \\
1 & 038 \\
1 & 805\end{array}$ \\
\hline \multicolumn{8}{|c|}{1986} \\
\hline $\begin{array}{l}\text { September } \\
\text { October } \\
\text { December }\end{array}$ & $\begin{array}{l}210 \\
123\end{array}$ & & 3142 & $\begin{array}{l}4701 \\
1029\end{array}$ & $\begin{array}{ll}1 & 515 \\
1 & 020\end{array}$ & $\begin{array}{l}312 \\
224\end{array}$ & $\begin{array}{l}788 \\
360\end{array}$ \\
\hline \multicolumn{8}{|c|}{1987} \\
\hline $\begin{array}{l}\text { September } \\
\text { October } \\
\text { November } \\
\text { December }\end{array}$ & $\begin{array}{r}2357 \\
151 \\
2759 \\
260\end{array}$ & & 670 & $\begin{array}{l}6712 \\
4870 \\
1016\end{array}$ & $\begin{array}{r}2902 \\
404 \\
1498\end{array}$ & 302 & $\begin{array}{l}658 \\
908\end{array}$ \\
\hline \multicolumn{8}{|c|}{1988} \\
\hline $\begin{array}{l}\text { August } \\
\text { September } \\
\text { October }\end{array}$ & $\begin{array}{l}177 \\
485\end{array}$ & & $\begin{array}{ll}3 & 355 \\
1 & 019\end{array}$ & 10599 & 2241 & 568 & 1194 \\
\hline
\end{tabular}

1989

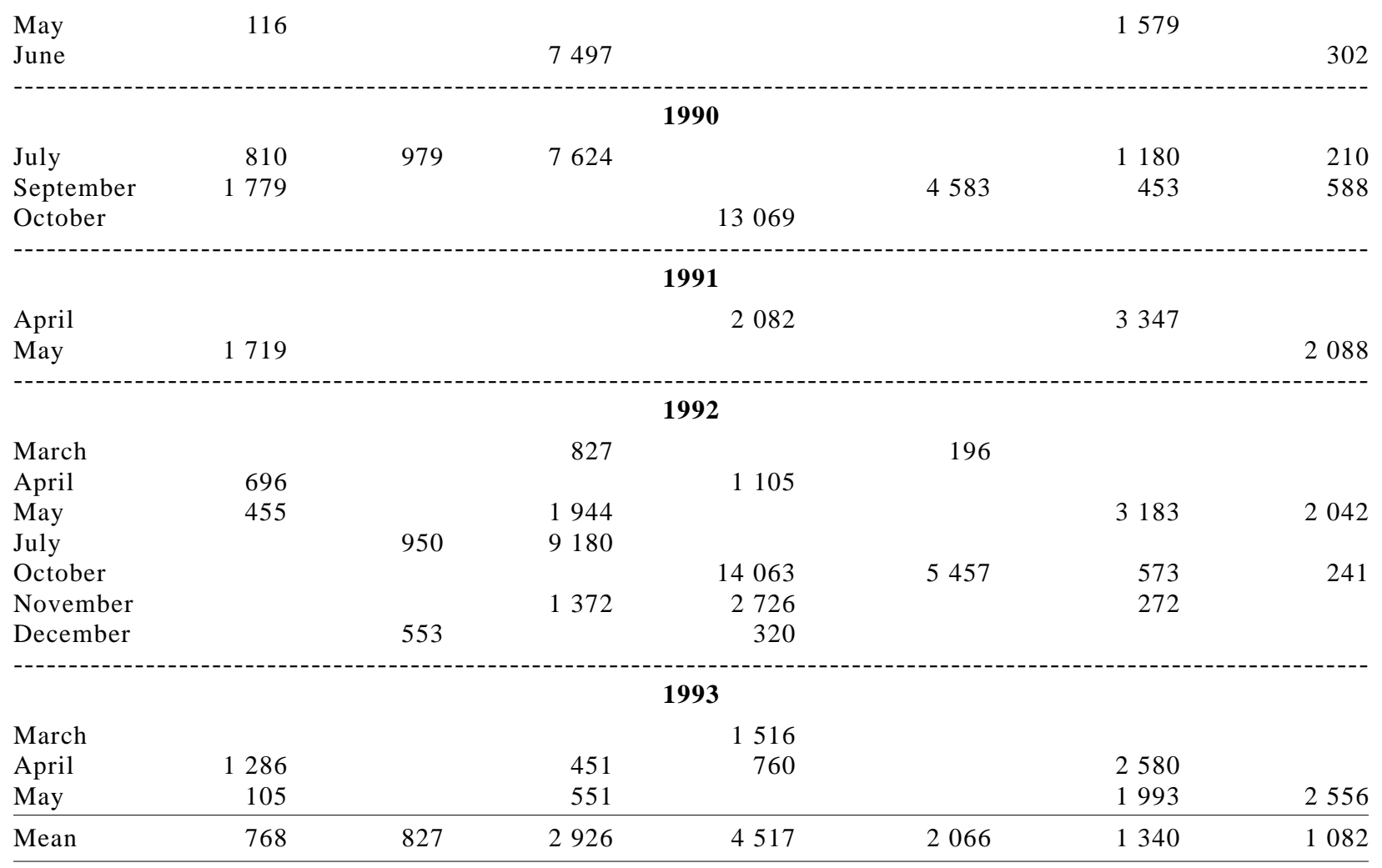




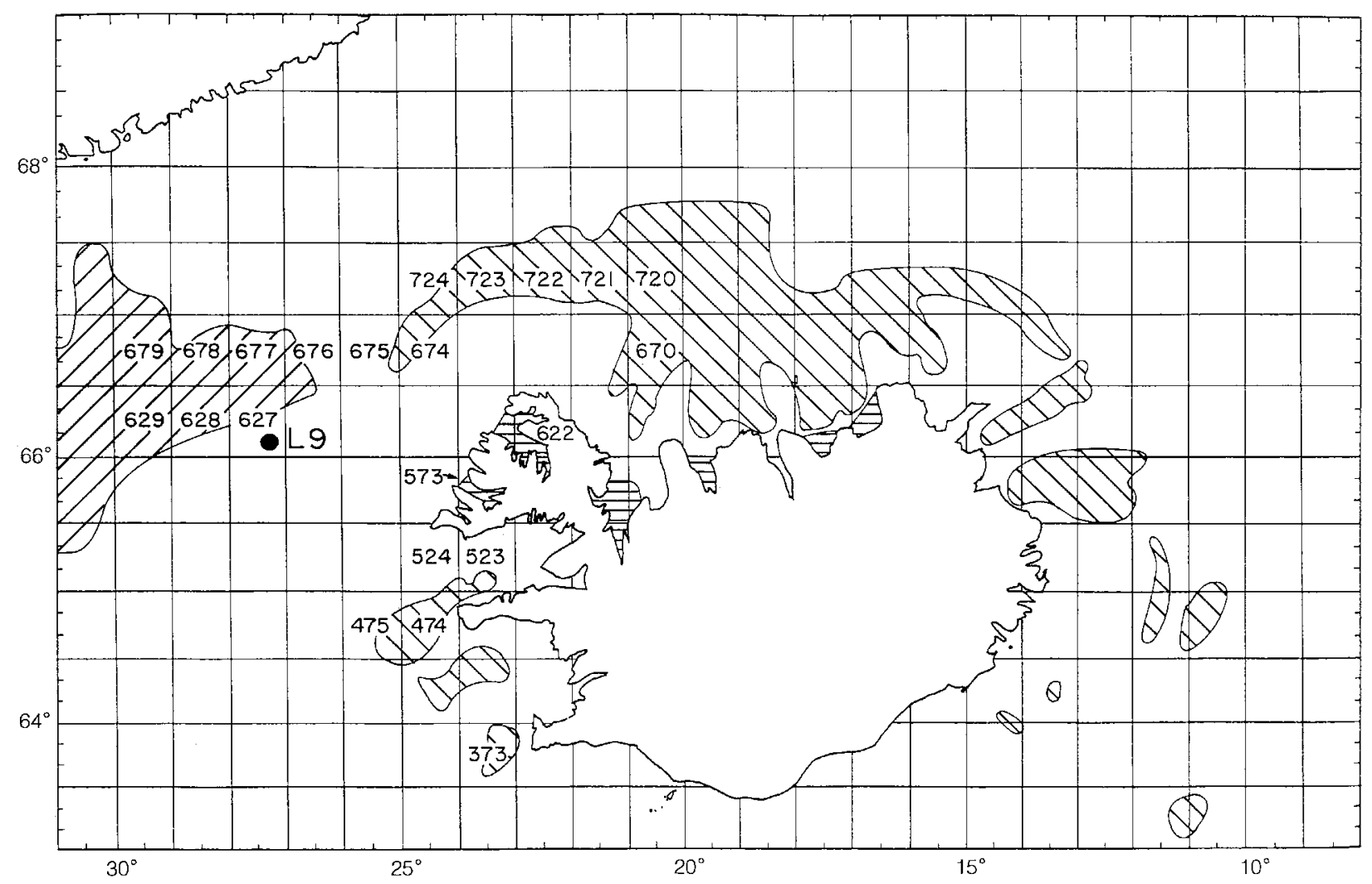

Fig. 1. The shrimp grounds in Denmark Strait and Icelandic waters. Strata Numbers used in the paper are shown on this map. The temperature station Látrabjarg 9 (L9) is indicated.

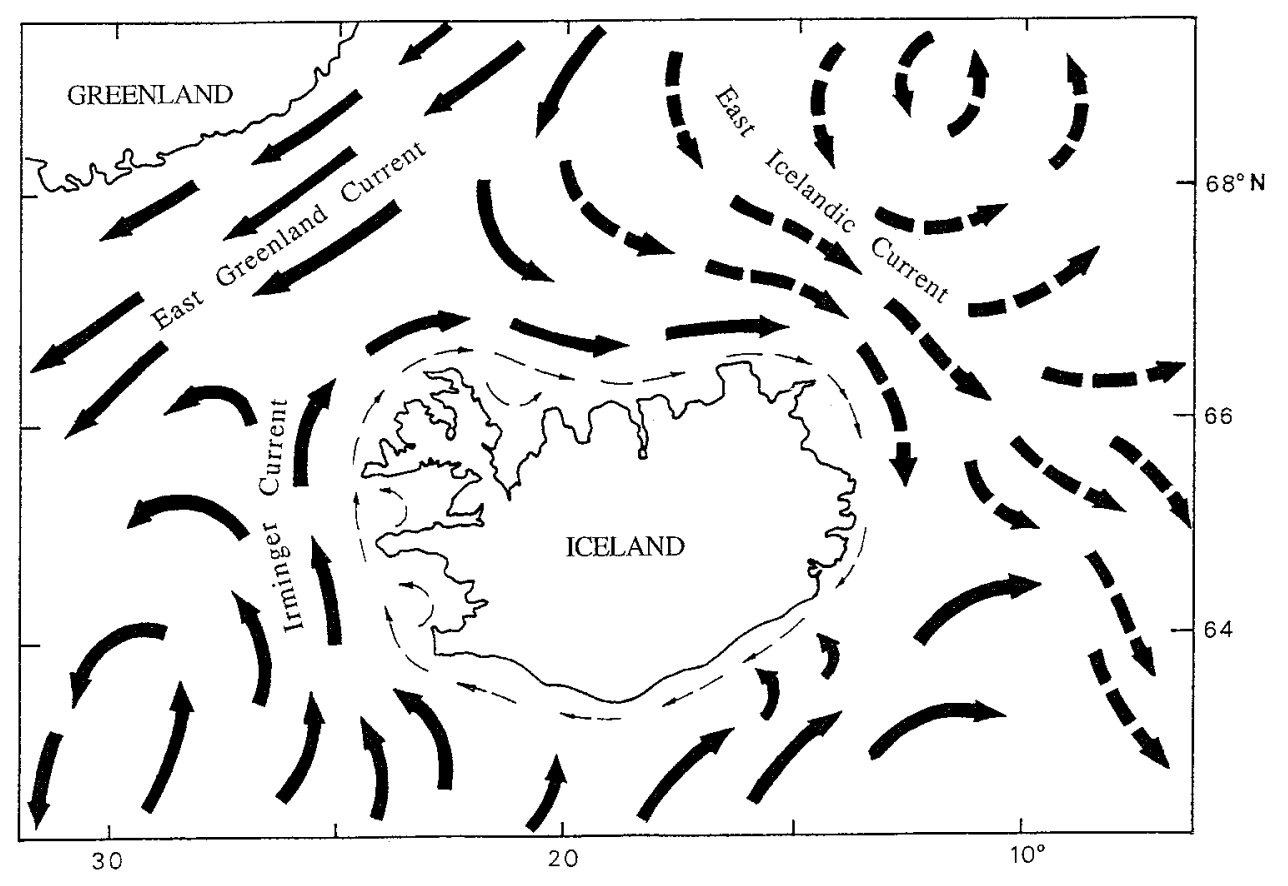

Fig. 2. The three main ocean currents around Iceland. The two currents coming from north are cold and the current coming from south is warm. The coastal current is indicated by fine arrows. The figure is adapted from Gunnarsson (1991). 


\section{Results}

One maturity ogive was fitted to all available samples for the same month and area. Here only the calculated $\mathrm{L}_{50}$ are presented (Table 2), but most of the ogives have been presented by Skúladóttir (1995). The calculated $\mathrm{L}_{50}$ of shrimp in the Denmark Strait area are listed as well as the $\mathrm{L}_{50}$ of other nearby areas in Icelandic waters. The $\mathrm{L}_{50}$ of Nordurkantur (Strata Numbers 720-724) were generally 3.5-4.6 $\mathrm{mm}$ smaller than those of Denmark Strait except in May 1992 where there was a difference of only $2.2 \mathrm{~mm}$. In spite of there being only a short distance between the Denmark Strait area and Hali (Strata Numbers 674 and 675), the $\mathrm{L}_{50}$ of the latter area were similar to those of Nordurkantur.

The $\mathrm{L}_{50}$ of the inshore areas were much smaller than those of all the offshore areas, namely 17.6$19.8 \mathrm{~mm}$ for Ísafjardardjup (Stratum Number 622), 18.2-21.8 mm for Arnarfjordur (Stratum Number 573 ), and 18.8-22.3 mm for Eldey (Stratum Number 373). Snaefellsnes (Strata Numbers 474, 523524) is often designated an offshore area as shrimp occur in deeper water than in the fjords, however, since the temperature regime is very different from that of the offshore areas in the north (see later), the area is therefore here called inshore. The $\mathrm{L}_{50}$ of Snaefellsnes area fall in the range 17.2-22.1 mm. Figure 3 shows the mean $\mathrm{L}_{50}$ for the years 1985-93 by area.

Table 3 presents results of the comparison of mean $\mathrm{L}_{50}$ of pairs of areas. There was a significant difference between the mean $\mathrm{L}_{50}$ of Denmark Strait to those of all other areas. The mean $\mathrm{L}_{50}$ of Nordurkantur was also significantly different from all other areas. The mean $\mathrm{L}_{50}$ of inshore areas were not significantly different from each other except for those of Isafjardardjup and Eldey.

The average annual temperatures of the period 1981-92 at the hydrographic Station L9 in the depth ranges $300-410 \mathrm{~m}$ and $402-540 \mathrm{~m}$ are shown in Tables 4 and 5 respectively. There was great variation in temperature between years, especially at the depth range 300-410 $\mathrm{m}$, where the annual mean temperature ranged from 0.4 to $4.92^{\circ} \mathrm{C}$. The overall average annual temperature for the years 198192 was $1.7^{\circ} \mathrm{C}$ at the depth range $300-410 \mathrm{~m}$, but only $0.4^{\circ} \mathrm{C}$ at the depth range $420-540 \mathrm{~m}$. The annual mean temperature in the depth range 420-540 $\mathrm{m}$ was from 0 to $0.75^{\circ} \mathrm{C}$, i.e. with much less variation than in shallower water.

\section{Discussion}

The $\mathrm{L}_{50}$ for female maturity in the Denmark Strait in August and September 1988 was $28.1 \mathrm{~mm}$ on average compared to 27.9 and $28.3 \mathrm{~mm}$ for samples from August and September, respectively (Table 1). If occasional migrations from areas with different mean $\mathrm{L}_{50}$ had occurred, these would be hidden when samples from all months were combined by year. From Table 2, however, there appears to be some stability for the $\mathrm{L}_{50}$ in most areas over the year.

Seasonality in the $\mathrm{L}_{50}$ of mature female shrimp in the Denmark Strait would be expected to show up in the ogives, namely with a small decrease when a new group of transitioning shrimp joins the spawning group of females in July-August, but there were no definite indications of such decreases in this study. On the whole, the $\mathrm{L}_{50}$ in the Denmark Strait did not change to any great extent through the years observed, consistently showing values greater than $27 \mathrm{~mm}$ except for September 1990, where the $\mathrm{L}_{50}$ was $26.5 \mathrm{~mm}$. The cause for this low value is a matter for speculation. There could have been an influx of shrimps in September 1990 from strata numbers $720-724$ or 674-675 to the Denmark Strait area, bringing smaller mature females than are usually seen there. Another possibility is that there were some early sex changes in the Denmark Strait area. Such transitions are known to occur. Rasmussen (1953, 1969) observed two modes of transitionals in the same population, indicating that the whole year-class might not change sex in the same year. Horsted and Smidt (1956) also noted something similar. Nevertheless, the former theory seems more plausible, as the $\mathrm{L}_{50}$ for the Denmark Strait were quite normal both in July 1990 at 27.6 $\mathrm{mm}$ and May 1991 at $28.5 \mathrm{~mm}$ during the months which fall within the same breeding season as the September 1990 shrimp population.

In Icelandic waters, temperature and $\mathrm{L}_{50}$ appeared to be roughly inversely related (Skúladóttir et al. MS 1991). For example, the $\mathrm{L}_{50}$ at Nordurkantur was $23.0-24.9 \mathrm{~mm}$ where the average near-bottom temperature for the period 197489 was $0^{\circ} \mathrm{C}$. In Isafjardardjup the mean near-bottom temperature was $4.5^{\circ} \mathrm{C}$ and $\mathrm{L}_{50}$ was between 17.6-19.8 m. Snaefellsnes, where the warm Irminger current is very prominent, had near-bottom temperature of $6^{\circ} \mathrm{C}$ in the 1991 study and the $\mathrm{L}_{50}$ was between 17.2 and $22.1 \mathrm{~mm}$. 
TABLE 2. The calculated $\mathrm{L}_{50}(\mathrm{~mm})$ of northern shrimp by month and year for areas in the Denmark Strait as compared to the $\mathrm{L}_{50}$ of the nearest areas in Icelandic waters.

\begin{tabular}{|c|c|c|c|c|c|c|c|}
\hline \multirow[b]{2}{*}{$\begin{array}{l}\text { Year } \\
\text { Month }\end{array}$} & \multirow[b]{2}{*}{$\begin{array}{c}\text { Denmark Strait } \\
627-629 \\
676-679\end{array}$} & \multicolumn{6}{|c|}{ Areas and Strata Numbers } \\
\hline & & $\begin{array}{c}\text { Hali } \\
674-675\end{array}$ & $\begin{array}{c}\text { Nordurkantur } \\
720-724\end{array}$ & $\begin{array}{c}\text { Ísafjardardjup } \\
622\end{array}$ & $\begin{array}{c}\text { Arnarfjordur } \\
573\end{array}$ & $\begin{array}{c}\text { Snaefellsnes } \\
474 \\
523-524\end{array}$ & $\begin{array}{c}\text { Eldey } \\
373\end{array}$ \\
\hline \multicolumn{8}{|c|}{1985} \\
\hline July & 28.3 & & & & & 20.0 & 20.7 \\
\hline August & 27.5 & & 23.4 & & & & 21.1 \\
\hline Sept./Oct. & & & & 19.8 & 20.5 & 21.3 & 21.6 \\
\hline November & 27.3 & & & 19.6 & 21.8 & & \\
\hline December & 27.7 & & & & & & \\
\hline \multicolumn{8}{|c|}{1986} \\
\hline September & & & 23.7 & & & 20.5 & 20.8 \\
\hline October & 27.3 & & & 18.7 & 18.8 & 21.7 & 20.8 \\
\hline December & 28.8 & & & 19.1 & 18.2 & & \\
\hline \multicolumn{8}{|c|}{1987} \\
\hline September & 27.6 & & 23.0 & & & 21.2 & 21.7 \\
\hline October & 29.3 & & & 19.0 & 19.4 & & 22.3 \\
\hline November & 28.3 & & & 19.8 & 21.5 & & \\
\hline December & 28.6 & & & 19.4 & 18.9 & & \\
\hline \multicolumn{8}{|c|}{1988} \\
\hline August & 28.3 & & 23.9 & & & 19.9 & 21.4 \\
\hline September & 27.9 & & 24.0 & & 19.4 & & \\
\hline October & & & & 19.3 & & & \\
\hline \multicolumn{8}{|c|}{1989} \\
\hline May & 28.8 & & & & & 17.2 & \\
\hline June & & & 24.8 & & & & 18.8 \\
\hline \multicolumn{8}{|c|}{1990} \\
\hline July & 27.6 & 24.4 & 24.1 & & & 20.4 & 20.1 \\
\hline September & 26.5 & & & & 19.1 & 22.1 & 21.5 \\
\hline October & & & & 17.6 & & & \\
\hline \multicolumn{8}{|c|}{1991} \\
\hline April & & & & 18.6 & & 18.9 & \\
\hline May & 28.5 & & & & & & 19.6 \\
\hline \multicolumn{8}{|c|}{1992} \\
\hline March & & & 24.4 & & 19.6 & & \\
\hline April & 27.7 & & & 19.2 & & & \\
\hline May & 27.1 & & 24.9 & & & 18.3 & 19.5 \\
\hline & & 24.0 & 24.0 & & & & \\
\hline October & & & & 18.2 & 19.9 & 20.1 & 21.4 \\
\hline November & & & 23.5 & 18.6 & & 19.8 & \\
\hline December & & 24.5 & & 18.3 & & & \\
\hline \multicolumn{8}{|c|}{1993} \\
\hline March & & & & 18.5 & & & \\
\hline April & 27.4 & & 24.1 & 19.4 & & 18.8 & \\
\hline May & 27.1 & & 23.4 & & & 17.7 & 20.3 \\
\hline Mean & 27.9 & 24.3 & 23.9 & 18.9 & 19.7 & 19.9 & 20.8 \\
\hline Number & 20 & 3 & 13 & 16 & 11 & 15 & 15 \\
\hline Standard error & 0.16 & 0.15 & 0.15 & 0.16 & 0.34 & 0.37 & 0.25 \\
\hline
\end{tabular}




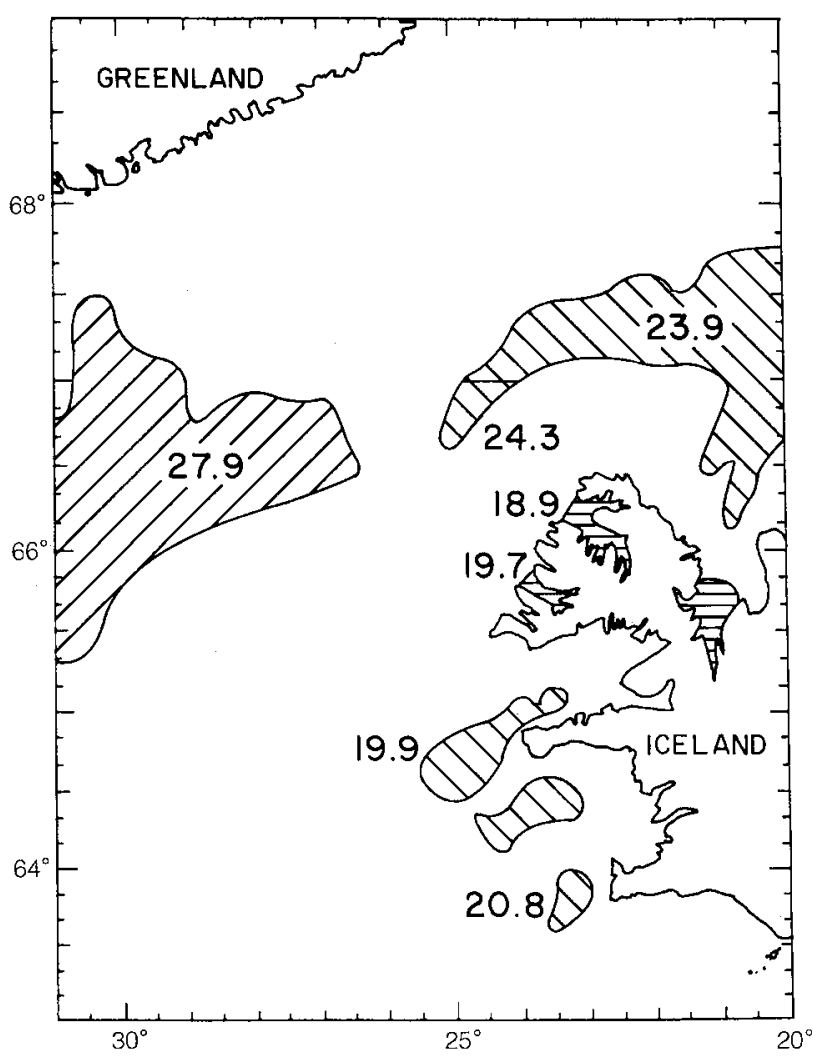

Fig. 3. The mean $\mathrm{L}_{50}$ of females at first maturity for the years $1985-93$ by area.
The shrimp grounds in the Denmark Strait seem to coincide mainly with the area covered by the socalled Arctic intermediate layer (Gade et al.; 1965, Stein, 1988), the temperature being between 0 and $2^{\circ} \mathrm{C}$. The temperature of $1.7^{\circ} \mathrm{C}$ at the depth range of $300-410 \mathrm{~m}$ at Station L9 appears to be within this range. This is also typical of the depth range from which most of the Denmark Strait shrimp samples were taken. It must be pointed out, however, that the temperature station lies farther to the east, i.e. where there are great fluctuations in the sea due to the variable flow west from the Irminger current. This is evident from the great interannual variation in temperature (Table 4). It is not known how far to the west the pulses of warm Atlantic water reach in the apparently warm years.

Very little is known about larval drift in this area when $P$. borealis larvae occur in a pelagic stage. The pelagic stage of $P$. borealis larvae has been found to be over two months in Isafjardardjup (Ásthórsson and Gíslason, 1991). One would expect larval drift to occur along with the prevailing current, and the shrimp larvae could thus be carried from one fjord to another. If this is the case the size at first spawning and the subsequent growth

TABLE 3. The comparison of mean $\mathrm{L}_{50}$ of two areas at a time are tabulated giving the calculated t-value ( $\mathrm{t}$ ), significant difference (signif.) and number of degrees of freedom (f).

\begin{tabular}{|c|c|c|c|c|c|}
\hline Strata Numbers & $720-724$ & 622 & 573 & $\begin{array}{c}474 \\
523-524\end{array}$ & 373 \\
\hline $\begin{array}{l}627-629 \\
676-679\end{array}$ & $\begin{array}{l}t=17 \\
f=31 \\
\text { signif. }\end{array}$ & $\begin{array}{c}\mathrm{t}=39.7 \\
\mathrm{f}=34 \\
\text { signif. }\end{array}$ & $\begin{array}{l}\mathrm{t}=27.3 \\
\mathrm{f}=33 \\
\text { signif. }\end{array}$ & $\begin{array}{l}t=17.5 \\
\mathrm{f}=19 \\
\text { signif. }\end{array}$ & $\begin{array}{c}\mathrm{t}=25.2 \\
\mathrm{f}=33 \\
\text { signif. }\end{array}$ \\
\hline $720-724$ & & $\begin{array}{c}t=22.6 \\
f=28 \\
\text { signif. }\end{array}$ & $\begin{array}{l}\mathrm{t}=11.3 \\
\mathrm{f}=14 \\
\text { signif. }\end{array}$ & $\begin{array}{l}\mathrm{t}=10.1 \\
\mathrm{f}=19 \\
\text { signif. }\end{array}$ & $\begin{array}{c}\mathrm{t}=10.48 \\
\mathrm{f}=26 \\
\text { signif. }\end{array}$ \\
\hline 622 & & & $\begin{array}{c}\mathrm{t}=2.5 \\
\mathrm{f}=14 \\
\text { not signif. }\end{array}$ & $\begin{array}{c}\mathrm{t}=2.3 \\
\mathrm{f}=19 \\
\text { not signif. }\end{array}$ & $\begin{array}{l}t=6.4 \\
f=29 \\
\text { signif. }\end{array}$ \\
\hline $\begin{array}{l}474 \\
523-524\end{array}$ & & & no difference & & $\begin{array}{c}\mathrm{t}=2.0 \\
\mathrm{f}=28 \\
\text { not signif. }\end{array}$ \\
\hline 573 & & & & & $\begin{array}{c}\mathrm{t}=2.5 \\
\mathrm{f}=24 \\
\text { not signif. }\end{array}$ \\
\hline
\end{tabular}


TABLE 4. Temperature $\left({ }^{\circ} \mathrm{C}\right)$ in the Denmark Strait at the depth range $300-420 \mathrm{~m}$ at $66^{\circ} 09^{\prime} \mathrm{N}-27^{\circ} 15^{\prime} \mathrm{W}(\mathrm{Station}$ L9) by month and year.

\begin{tabular}{|c|c|c|c|c|c|c|c|c|c|c|c|c|c|}
\hline \multirow[b]{2}{*}{ Month } & \multicolumn{13}{|c|}{ Year } \\
\hline & 1981 & 1982 & 1983 & 1984 & 1985 & 1986 & 1987 & 1988 & 1988 & 1990 & 1991 & 1992 & Mean \\
\hline January & & 1.05 & & & & & & & & & & & \\
\hline February & & & 1.18 & 0.45 & 0.85 & 0.41 & 0.74 & 1.47 & 0.62 & 3.78 & 1.45 & 1.43 & 1.24 \\
\hline March & 1.33 & & & & & & & & & & & & \\
\hline May & 0.13 & 0.45 & 0.72 & 0.27 & 1.11 & 1.02 & 2.84 & 1.54 & 0.71 & & 0.74 & 1.35 & 0.99 \\
\hline August & 0.55 & -0.31 & 0.16 & 0.48 & 0.44 & 5.66 & 2.98 & -0.24 & 0.01 & 4.86 & & & \\
\hline September & & & & & & & & & & & 5.89 & 0.22 & 1.73 \\
\hline October & & & & & & 1.08 & 0.89 & 0.18 & & & & 5.82 & \\
\hline November & 6.35 & & & 0.58 & 1.21 & & & & 0.75 & 6.12 & 5.46 & & 2.84 \\
\hline Mean & 2.09 & 0.40 & 0.69 & 0.45 & 0.90 & 2.04 & 1.86 & 0.74 & 0.52 & 4.92 & 3.39 & 2.21 & 1.70 \\
\hline
\end{tabular}

TABLE 5. Temperature $\left({ }^{\circ} \mathrm{C}\right)$ in the Denmark Strait at the depth range $420-540 \mathrm{~m}$ at Station L9 by month and year.

\begin{tabular}{|c|c|c|c|c|c|c|c|c|c|c|c|c|c|}
\hline \multirow[b]{2}{*}{ Month } & \multicolumn{13}{|c|}{ Year } \\
\hline & 1981 & 1982 & 1983 & 1984 & 1985 & 1986 & 1987 & 1988 & 1989 & 1990 & 1991 & 1992 & Mean \\
\hline January & & 0.03 & & & & & & & & & & & \\
\hline February & & & -0.10 & 0.71 & 0.05 & 0.17 & 0.23 & 1.01 & -0.11 & 0.19 & 0.49 & 0.98 & 0.34 \\
\hline March & 0.41 & & & & & & & & & & & & \\
\hline May & 0.14 & 0.30 & -0.22 & 0.29 & 0.45 & 0.23 & -0.08 & 0.60 & -0.14 & & 0.21 & 0.59 & 0.22 \\
\hline August & 0.26 & -0.28 & 0.31 & 0.19 & -0.03 & 1.96 & 0.50 & -0.48 & 0.58 & 0.45 & & & \\
\hline September & & & & & & & & & & & 0.46 & 0.19 & 0.34 \\
\hline October & & & & & & 0.64 & 0.05 & 0.25 & & & & 0.66 & \\
\hline November & 2.02 & & & 0.04 & 0.00 & & & & 0.39 & 0.70 & 0.43 & & 0.52 \\
\hline Mean & 0.71 & 0.02 & 0.00 & 0.31 & 0.12 & 0.75 & 0.18 & 0.35 & 0.18 & 0.45 & 0.40 & 0.61 & 0.35 \\
\hline
\end{tabular}

of larvae will be affected by the temperature in the ocean current environment. This in turn relates to the larvae that settle in that particular area. Thus the population as characterized by a given size of $\mathrm{L}_{50}$ would only be temporary, or related to the settlement of the larvae. If on the other hand the shrimp larvae have means of maintaining themselves in the area where released, by sinking below the main stream or by actively moving back to the place where they were released, then there is a chance for the formation of a distinct population of $P$. borealis in that area.
The genetic structure of $P$. borealis population in Icelandic waters has been studied with electrophoresis performed on 13 loci (Jónsdóttir, 1996). Three of these loci were found to be polymormphic and 10 monomorphic, and the analysis of these data using cluster and principal component analyses resulted in the recognition of three populations, one inshore, one offshore and one contained within the Denmark Strait. Therefore, the findings of Jonsdottir (1996) support the theory that the three areas remain isolated from each other with respect to dispersal of larvae. 
The first known attempt to determine the ageat-length of the Denmark Strait shrimp was carried out by Smedstad (MS 1990), who estimated females to be 6 years old when they spawn for the first time. Skúladóttir (MS 1994) carried out some preliminary age determination of shrimp from the same area and estimated females to be one year older at first spawning. Shrimp from the Nordurkantur area spawn for the first time at the age of 6 years according to preliminary ageing, while shrimp in both Snaefellsnes and in Isafjardardjúp are assumed to spawn for the first time at the age of 3 (Skúladóttir et al., MS 1991).

The $\mathrm{L}_{50}$ and size at first spawning are not the same by definition. The latter is usually slightly larger than the $\mathrm{L}_{50}$ for the same sample. In the absence of any published $\mathrm{L}_{50}$ values for $P$. borealis for this study area, the comparison had to be limited to the size at first spawning. The age and approximate size of females spawning for the first time at Nordurkantur in fact was not very unlike those found in some areas in the Northwest Atlantic, such as St. Anthony Basin, where females were thought to spawn for the first time at the age of 6 and the mean length of the multiparous females was $24.1 \mathrm{~mm}$ for the years 1981 and 1983-86 (Parsons et al., 1989). The average annual bottom temperature ranged from $2^{\circ}$ to $4^{\circ} \mathrm{C}$ in the St. Antony Basin. For the Davis Strait shrimp, the mean size of multiparous females was $26.2 \mathrm{~mm}$ where the bottom temperature ranged from $1^{\circ}$ to $4^{\circ} \mathrm{C}$, the age being 7 or 8 years at first spawning (Parsons et al., 1989). The Denmark Strait shrimp is, as far as is known, the largest of all P. borealis when it changes sex, with $\mathrm{L}_{50}$ at $27.9 \mathrm{~mm}$ on the average. The northern shrimp of the Bering Sea is almost as large, where average $\mathrm{L}_{50}$ is reported at $27 \mathrm{~mm}$ and age 5.5 when spawning occurs for the first time as a female (Ivanov, 1969), and the average annual near-bottom temperature there is about $1.7^{\circ} \mathrm{C}$. The Barents sea is considered by Teigsmark (1983) to have three populations growing at different rates and females spawning for the first time at ages 4.5, 5.5 and 6.5 years, respectively. The annual near-bottom temperatures are approximately $3^{\circ}, 2^{\circ}$ and $1^{\circ} \mathrm{C}$ respectively in each area. However, the size at first female maturity is not very variable between the populations, namely from 20.5-21.4 in the years 1978 and 1979 (Teigsmark, 1983) with the largest variation occurring in the coldest area. In Icelandic waters, e.g. in Isafjardardjup and at Snaefellsnes, where average annual near-bottom temperature is $4.5^{\circ}$ and $6^{\circ} \mathrm{C}$ respectively, the females spawn for the first time at the age of 3 years and the $\mathrm{L}_{50}$ range from 17.7 to $20.1 \mathrm{~m}$. In the North Sea, where the average annual near-bottom temperature is about $6^{\circ} \mathrm{C}$, females spawn at the age of 1.5 years and the size at first female spawning is 17.0 to $17.8 \mathrm{~mm}$ (Anon., MS 1988).

Charnov (1982) has shown that the length of time spent as males tend to increase with increasing latitude. The findings in this study agree to some extent with this generally accepted theory, as have been reported by other authors that there is an increasing longevity and slower growth at higher latitudes and decreasing average temperatures (Rasmussen, 1953; Appolonio et al., 1986). However, the difference in growth rate does not result in sex change occurring at a similar size in different areas, as Rasmussen postulated (1953).

In similar crustacean research, Estrella and McKiernan (1989) found that size at maturity of female lobster, Homarus americanus off the coast of Massachusetts was related to summer temperature, namely the higher the temperature the smaller the $\mathrm{L}_{50}$. However, from various investigations on fish it becomes evident that there are no fixed rules as to whether fast growth will bring about early maturity at a large size. Similarly, there can also be late maturity at a large size and late maturity at a small size. Stearns and Crandall (1983) maintain that organisms neither mature at a fixed size nor fixed age within the same species, and proposing that these factors are determined both by genes and environment.

\section{Conclusions}

In the geographic coverage of this study, there seem to be at least three identifiable environmental regimes, which resulted consistently showing three size categories of $\mathrm{L}_{50}$ at which female $P$. borealis begin to show sexual maturity. In the Denmark Strait, where near-bottom temperature might be $0-2{ }^{\circ} \mathrm{C}$, the $\mathrm{L}_{50}$ for females at first maturity was between $26.5 \mathrm{~mm}$ and $29.3 \mathrm{~mm}$. In the offshore area north of Iceland (Strata 720-724) with the average bottom temperature of $0^{\circ} \mathrm{C}$, the median maturity length was between 23 and $24.9 \mathrm{~mm}$, and the inshore areas along the west coast where temperature ranges from $4.5-6^{\circ} \mathrm{C}$ and $\mathrm{L}_{50}$ was always below $22 \mathrm{~mm}$ and usually between 17.0 and $21.4 \mathrm{~mm}$. The consistency of the $\mathrm{L}_{50}$ values in each area was such 
that the mean $\mathrm{L}_{50}$ can possibly be used as a criterion for describing a population. Genetical findings of Jónsdóttir (1996) also support the theory of three separate populations of $P$. borealis in Icelandic waters with respect to larval dispersal. Thus the differences in $\mathrm{L}_{50}$ in the three defined areas, namely inshore, offshore and Denmark Strait, seem to indicate phenotypical as well as genetical differences.

There appears to be an inverse relationship between temperature and size at first spawning for females. This was particularly true in the very few areas of Icelandic waters where the average near-bottom temperature has been recorded over many years.

There is not only geographic variation in the growth and longevity of northern shrimp, but also some variation in the size of females at first spawning.

\section{Acknowledgements}

I am indebted to Gunnar Pétursson for carrying out all the calculations and plotting of the maturity ogives and respective constants. Thanks are due to Odd Smedstad for providing many shrimp samples from the Denmark Strait in 1987. Thanks are also due to the crews of several Icelandic shrimp vessels that have provided the Marine Research Institute with numerous shrimp samples. Among them are "Helga", "Hrafn Sveinbjarnarson II" and "Gissur. I also wish to thank Sigurdur Gunnarsson for Fig. 1 and 3.

\section{References}

ANON. MS 1988. Report of the working group on the assessment of stocks. ICES C.M. Doc., No. Assess: $14,37 \mathrm{p}$.

APPOLONIO, S., D. K. STEVENSON, and E. E. DUNTON, Jr. 1986. Effects of temperature on the biology of the northern shrimp Pandalus. borealis, in the Gulf of Maine. NOAA Tech. Rep., NMFS 42, $22 \mathrm{p}$.

ASHTON, W. D. 1972. The logit transformation with special reference to its uses in bioassay. Hafner Publ. Co. New York, 88 p.

ÁSTHÓRSSON Ó. S., and Á. GÍSLASON. 1991. Seasonal abundance and distribution of Caridea larvae in Ísafjord-deep, North-west Iceland. J. Plankton Res., 13: 91-102.

BAILEY, N. T. J. 1959. Statistical methods in biology. The English Universities Press Ltd., 200 p.

BLISS, C. L. 1934. The method of probits. Science, 79: 12 January.

CHARNOV, E. L. 1982. The theory of sex allocation. Princeton University Press, Princeton, New Jersey,
$355 \mathrm{p}$.

CHARNOV, E. L., and P. J. ANDERSON. 1989. Sex change and population fluctuations in pandalid shrimp. Amer. Natur., 134: 824-827.

ESTRELLA, B. T., and D. J. MCKIERNAN. 1989. Catchper-unit-effort and biological parameters from the Massachussetts coastal lobster (Homarus americanus). Resource Description and trends. NOAA Tech. Rep., NMFS 81:21 p.

GADE, H. G., S. AA. MALMBERG, and U. STEFÁNSSON. 1965. Report on the joint Icelandic-Norwegian expedition to the area between Iceland and Greenland, 1963. NATO Subc. Oceanogr. Res. Tech. Rep., 22: 59 p. (Irminger Sea Project).

GUNNARSSON, K. 1991. Populations de Laminaria hyperborea et Laminaria digitata (Phéophycées) dans la baie de Breidifjordur, Islande. J. Mar. Res. Inst., Reykjavik, 12(1): 148 p.

HORSTED, S. AA., and E. SMIDT. 1956. The deep sea prawn (Pandalus borealis Kr.)in Greenland waters. Medd. Dan. Fisk.-Havunders., N.S., 1(11): 118 p.

IVANOV, B. G. 1969. Biology of the northern shrimp (Pandalus borealis Kr.) in the Gulf of Alaska and the Bering Sea. Tr. VNIRO, 65: 392-416. (Trans. Fish. Res. Board Can., Transl. Ser. No. 1576, 1970).

JÓNSDÓTTIR, Ó. D. 1996. Population genetic studies of northern shrimp (Pandalus borealis Kr. ) in Icelandic waters and Denmark Strait. Cand Scient Thesis. Univ. of Bergen, Norway, 96 p.

MALMBERG, S. A., and S. S. KRISTMANNSSON. 1992. Hydrographic conditions in Icelandic waters, 1980-1989. ICES Mar. Sci. Symp., 195: 76-92.

McCRARY, J. A. 1971. Sternal spines as a characteristic for differentiating between females of some Pandalidae. J. Fish. Res. Board Can., 28: 98-100.

PARSONS, D. G, V. L. MERCER, and P. J. VEITCH. 1989. Comparison of the growth of Northern shrimp (Pandalus borealis) from four regions of the Northwest Atlantic. J. Northw. Atl. Fish. Sci., 9: 123-131.

PEARL, R., and L. J. REED. 1920. On the rate of growth of the population of the U.S. since 1790 and its mathematical representation. Proc. Natl. Acad. Sci., 6: 275-288.

RASMUSSEN, B. 1953. On the geographical variation in growth and sexual development of the deep sea prawn (Pandalus borealis Kr.). Fiskeridir. Skr. Havunders., 10(3): 160 p.

1969. Variation in protandric hermaphroditism of Pandalus borealis. FAO Fish. Rep., 57: 11011106.

SKÚLADÓTTIR, U. MS 1990. Defining stocks of Pandalus borealis off Northern Iceland using the maximum length and maturity ogive of females as a measure. ICES symposium on shellfish histories and shell fishery models in Moncton, 1990, No. 95, $19 \mathrm{p}$.

MS 1994. The Icelandic shrimp fishery (Pandalus borealis) in the Denmark Strait in 1992-1994, and a preliminary estimation of age. 
NAFO SCR Doc., No. 97, Serial No. N2286, 10 p. MS 1995. The Female Sexual Maturity of Northern Shrimp (Pandalus borealis Kr.) in Denmark Strait in the Years 1985-1993 and a Comparison to the Nearest Icelandic Shrimp Populations. NAFO SCR Doc., No. 14, Ser. No. N2521, 15 p.

SKÚLADÓTTIR, U., J. PÁLSSON, G. S. BRAGASON, and S. BRYNJÓLFSSON. MS 1991. The variation in size and age at change of sex, maximum length and length of ovigerous periods of the shrimp, Pandalus borealis, at different temperatures in Icelandic waters. ICES C.M. Doc., No. K: 5, 15 p.

SKÚLADOTTIR, U., and E. JÓNSSON. 1980. Raekjan vid Ísland. Aegir, 73(2): 86-96 (in Icelandic).

SMEDSTAD, O. MS 1990. Preliminary report of a cruise with M/T Håkøy-II to East Greenland Waters in September 1989. NAFO SCR Doc., No. 90, Ser. No. N1724, 13 p.

STEARNS, S. C., and R. E. CRANDALL. 1983. Plasticity for age and size at sexual maturity: A life-history response to unavoidable stress. G. W. Potts and R. J. Wootton (eds.). Fish reproduction: Strategies and tactics. Academic Press Inc., London Ltd., p. 11-33.

STEIN, M. 1988. Variability of water masses, currents and ice in Denmark Strait. NAFO Sci. Coun. Studies, 12: 71-84.

TEIGSMARK, G. 1983. Populations of the deep-sea shrimp (Pandalus borealis Krøyer) in the Barents sea. Fiskeridir. Skr. Havunders., 17: 377-430. 
